\title{
デジタル画像相関法を用いた全視野変形・ひずみ測定の精度評価研究*
}

\author{
畎田道雄*1, 奥 畑峻*2, 石川憲一*3
}

\section{Study on Accuracy Evaluation of Deformation and Strain Distribution Measurement using Digital Image Correlation Method}

\author{
Michio UNEDA*4, Syun OKUHATA and Ken-ichi ISHIKAWA \\ ${ }^{* 4}$ Department of Mechanical Engineering, Kanazawa Institute of Technology, \\ 7-1 Ohgigaoka, Nonoichi, Ishikawa-gun, Ishikawa, 921-8501 Japan
}

\begin{abstract}
Sub-pixel digital image correlation (Sub-DIC) method is effective for health monitoring of structures, because the Sub-DIC method can measure full-field deformation and strain distribution. However, the effect of analysis parameters of Sub-DIC method on measurement accuracy is not clarified. In this paper, we discussed the relation between the analysis parameters and the measurement accuracy of the Sub-DIC method. We demonstrated the analysis parameters such as a sub-set size, scan-step interval, and averaged point size on the standard deviation of measured deform and strain error distributions. Moreover, we found measurement accuracy is correlation related to the half width of spatial FFT spectrum of measured object and strain distribution. Finally, it is basically confirmed the measurement accuracy of Sub-DIC method depends on the central limit theorem.
\end{abstract}

Key Words: Image Processing, Measurement, Accuracy, Deformation and Strain Distribution Measurement, Sub-Pixel Digital Images Correlation (Sub-DIC) Method

\section{1. 緒言}

昭和 30 年代から 40 年代の高度経済成長期において, .社会的インフラの急速な需要の高まりから橋梁やダム などの大型構造物が多く建造された。一方，高度経済成 長期から 40 年以上が経過した近年，それらの構造物の 老朽化が進み，その維持管理やリスク評価がより重要視 されるようになっており, 構造物の安全性や信頼性を評 価する新しい手法である構造へルスモニタリングが提 唱されている(1). 構造ヘルスモニタリングは，構造物に おける安全性及び信頼性評価の高効率化やコスト削減 を目的とした手法であり，その測定対象位変形，応力， 振動，腐食量など多岐にわたる，その中でも構造物に生 じる変形やひずみは，破壊に対する安全指標であるため， 特に継続的にモニタリングすべき対象の一つとされて おり ${ }^{(1)}$, 変形・ひずみ測定に求められる要求は高くなり つつある.

ところで，現在のところ一般的に使用される変形・ひ ずみ測定法の代表例として，接触式測定法であるひずみ ゲージ法が挙げられる. ゲージ法は, 安価な測定器で高 精度のひずみ測定が可能であることから，構造物に加わ

* 原稿受付 2009 年 9 月 10 日.

*1 正員, 金沢工業大学工学部(画921-8501 石川県石川郡野々 市町搨が丘 7-1)

*2 学生員, 金沢工業大学大学院工学研究科.

*3 正員, 永年会員, 金沢工業大学.

E-mail : uneda@neptune.kanazawa-it.ac.jp
る荷重・応力状態測定などに幅広く利用されている，し かしながら，ゲージ貼り付けの人的コストが高いことや， 測定範囲が狭小であり，広範囲のひずみ分布測定には適 さないことなどが問題点とされている(2). それに対して， 広範囲の変形・ひずみ分布測定が可能である非接触式測 定法が開発され，その代表例にモアレ法やレーザホログ ラフィ干渉法などがある。しかし，これらの測定法も，

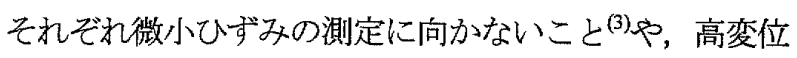
量の測定が困難であること(4)などから，その用途は未だ 限定的である.

このような状況を背景に，昨今のデジタルカメラの高 性能化により，新たな非接触式変形・ひずみ測定法とし て，サブピクセル処理を可能とするデジタル画像相関法 (以下，Sub-DIC 法）に関する研究が盛んに行われてい $ろ^{(5)-(15)}$. Sub-DIC 法は, デジタルカメラによって撮影し た画像全体の全視野変形・ひずみ分布測定が可能である. そのため, 構造物などの応力・荷重測定のみならず, 電 子基板のひずみ測定 ${ }^{(5)}$ P CFRP 積層板のひずみ測定 ${ }^{(6)}$, 歯 周組織の変形解析 ${ }^{(7)}$ など, 電子機器や医療の分野への適 用も検討され，その用途や重要性は今後さらに増大して いく考えられる.

ここで, Sub-DIC 法における測定精度に視点を向ける と，インテリジェントハイブリッド法(8)や輝度值へのラ

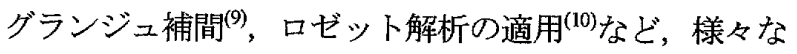
手法を併用して測定精度の向上を目的とする検討が行 
われている.さらに，サブピクセル処理にはピクセルロ ッキング現象と称される特有の誤差原因があることが 明らかにされている(11)，一方，測定対象物が有する表面 模様のランダム性やSub-DIC 法における解析パラメータ, 測定対象物に生じているひずみ状態を基本測定条件と 捉えると，基本測定条件が測定精度に及ぼす影響につい ての評価研究は少なく，測定精度との関係性は十分に解 明されていないと言えよう。

本研究はこのような観点に立脚し，Sub-DIC 法による 変形・ひずみ測定の基本測定条件が測定精度に及ぼす影 響について統計的に解明することを通じて，Sub-DIC 法 の測定精度に関する指針提示を目的としている.すなわ ち本論文においては，測定対象物の表面模様のランダム 性を，空間 FFT 解析を用いて定量評価するとともに，そ れが測定精度に及ぼす影響を明らかにする．また，変 形・ひずみ測定における解析パラメータの影響を検討し， さらには測定対象物にひずタが生じている場合の測定 精度への影響について実験的に検討した結果を述べる。

\section{2. デジタル画像相関法を用いた変形・ひずみ 分布測定法の概要と測定精度の評価方法}

$2 \cdot 1$ 変形・ひずみ分布測定法の概要 現在までに Sub-DIC 法に関して様々な観点から研究が行われている が，Sub-DIC 法による変形・ひずみ分布の算出方法は, それぞれの研究で少しずつ異なった方法が用いられて いる(5)(10k12)，変形・ひずみ分布の測定精度は算出方法の 影響も受けることから，本節では本研究において著者ら が用いた変形・ひずみ測定法について述べる。すなわち， 本論文における測定精度評価は本節の方法による結果 であり，他研究者によって提示される Sub-DIC 法のすべ てに適用できるものではないことを注意されたい．

本研究における Sub-DIC 法では, 測定対象物の基準と なる表面状態を基準画像としてデジタルカメラによっ て撮影後, 測定したい状態での測定対象物を比較画像と して撮影する.これらの画像を比較することによって， 測定対象物の表面に生じる変形・ひずみ分布測定を行う.

図 1 はSub-DIC法による変位測定の概要を示している. なお図 1 は，撮影した画像の一部を画素が確認できるレ ベルまで拡大したものである. 本研究で取り扱う測定法 では, 図 1(a)のように基準画像内の測定点 $A(i, j)$ を中心に, 一辺が S[pixel]となるサブセット領域と呼ばれる正方形 の微小領域を設定する。.このとき，比較画像内にも当該 座標（i,j) を中心に同一形状，サイズのサブセット領域 があると考える．このように，著者らが用いた方法では サブセットの変形を考慮していない，なお，サブセット

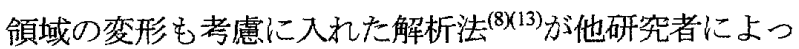

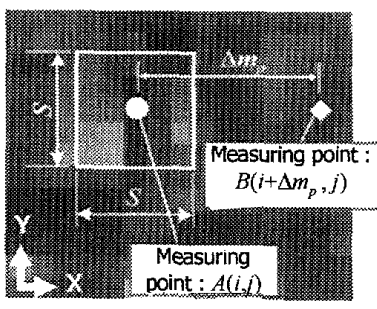

(a) Original image

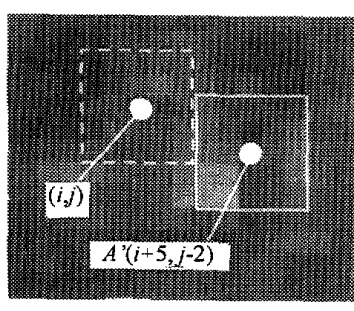

(b) Comparison image
Fig.1 Summary of deformation measurement by Sub-DIC

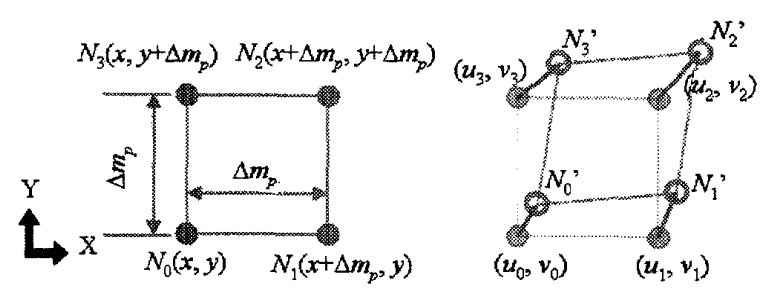

Fig.2 Calculation method of strain using deformation value measured

て既に提案・検討されていることを付記する．またこ こではS[pixel]をサブセットサイズと定義する.一例とし て, 基準画像撮影後に測定対象物が変形し, 測定点 $A$ が $\mathrm{X}$ 軸方向に 5pixel，Y 軸方向に-2pixel 変位した場合を考 えると，基淮画像中のサブセット領域は比較画像中で図 1(b)に示す位置となる. この変位量を残差自乗和相関 ${ }^{(14)}$ により求めることによって, 測定点 $A$ の変位を測定でき る. しかし実際には，測定対象物の変位量は 1pixel 単位 とならないことが多く，変位の測定分解能が 1pixel であ る方法では十分な精度が得られない，そこで相関の極值 近傍に，式(1)で与えられる関数を用いた応答曲面近似に よるサブピクセル処理を施し，サブピクセルレベルでの 変位測定を行った ${ }^{(14)}$.

$$
g(x, y)=a_{1} x^{2}+a_{2} y^{2}+a_{3} x y+a_{4} x+a_{5} y+a_{6}
$$

式(1)の係数 $\alpha_{h}(h: 1 \sim 6)$ は, ピクセルレベルでの相 関曲面の極值座標を $\left(m_{x 0}, m_{y 0}\right)$ としたとき, $\left(\mathrm{X}\right.$ 軸 : $m_{x 0}-1$, $\left.m_{x 0}, m_{x 0}+1\right) \times\left(\mathrm{Y}\right.$ 軸 : $\left.m_{30}-1, m_{y 0}, m_{30}+1\right)=$ 合計 9 点の 相関值を用いて最小二乗法により求めた。 なお，このよ うな方法で相関值に対してサブピクセル処理を施す場 合, 得られる変位が整数值に偏る現象，すなわち，ピク セルロッキング現象が発生する傾向にあることが知ら れている(11). 本論文ではピクセルロッキング現象がある ことを認識した上で, 著者らが用いた Sub-DIC 法に関す る解析条件と標準偏差の関係を検討した。

このようなサブピクセルレベルの変位測定を， $\Delta m_{p}[$ pixel] $]$ 間隔で格子状に隣り合うすべての測定点で 繰り返すことによって，画像全体の変形分布を求めた. 
なお, 測定点の閒隔である $\Delta m_{p}[$ pixel]をスキャンステップ 間隔と定義し，その大きさは X 軸方向及び $\mathrm{Y}$ 軸方向で 同一とした.

変形分布の測定後, 隣接する変位値とスキャンス テップ間隔 $\Delta m_{p}$ により，ひずみの算出を行う．本研 究では図 2 に示すように 1 つのひずみ測定点 $N_{0}(x, y)$ に対して，それを含む 4 つの測定点 $N_{k}(k: 0 \sim 3)$ の変位値を用いて算出した。すなわち, 点 $N_{k}$ で測定 される変位值を $\left(u_{k}, v_{k}\right)$ とするとき, 点 $N_{k}(k: 0 \sim 3)$ の中心点における $\mathrm{X}$ 軸ひずみ $\varepsilon_{x}, \mathrm{Y}$ 軸ひずみ $\varepsilon_{y}$ は式 (2)のようにして求めることができる.

$$
\begin{aligned}
& \varepsilon_{x}=\frac{\left(u_{1}+u_{2}\right)-\left(u_{0}+u_{3}\right)}{2 \Delta m_{p}} \\
& \varepsilon_{y}=\frac{\left(v_{2}+v_{3}\right)-\left(v_{0}+v_{1}\right)}{2 \Delta m_{p}}
\end{aligned}
$$

ところで，ひずみ測定の誤差を低減するには，口 ゼット解析の適用(10)などが検討されているが，本論 文では簡易な方法である平均化処理を用いて誤差の 低減を図った。平均化処理とは，測定点周辺のひず み值を平均し, その值を当該測定点のひずみ值とし て置き換える処理である.このとき平均化範囲は測 定点を中心とした正方形 $\left(P_{s} \times P_{s}\right)$ であり，ここでは 一辺に含まれる測定点数 $P_{s}$ を平均化処理サイズと 定義する.また，平均化処理範囲における一辺の長 さを $A_{s}[\mathrm{pixel}]$ と表すと， $A_{s}$ はスキャンステップ間隔 $\Delta m_{p}$ と平均化処理サイズ $P_{s}$ に対して式(3)のような関 倸が成り立つ. なお， $A_{s}$ を平均化エリアサイズと定 義する。

$$
A_{s}=\Delta m_{p} \cdot\left(P_{s}-1\right)
$$

本研究では Sub-DIC 法で必要となるサブセットサイ ズ S[pixel], スキャンステップ間隔 $\Delta m_{p}[$ pixel], 平均化処 理サイズ $P_{s}$, 平均化エリアサイズ $A_{s}[$ pixel] 04 つを解析 パラメータと定義する. なお, サブセットサイズ，スキ ヤンステップ閒隔，及び平均化処理サイズはそれぞれ大 きくなるほど解析結果の空間分解能は低下寸る.

\section{$2 \cdot 2$ 実験方法及び測定精度評価方法}

本研究では, 圾験片（アルミニウムA2017-T4, 厚さ $2 \mathrm{~mm}$ ）測定対象物とし，その全表面に黒色のスプレー 塗料を塗布した後, 白色のスプレー塗料をまだらに塗布 することによってランダムな表面模様を付与した. これ により作成した 3 種類の表面模様を撮影した画像の一部 を図 3 に示す.なお, 撮影した画像の pixel サイズは 2381 $\times 1901$ pixel，1pixel の大きさは約 $12 \mu \mathrm{m}$ である.また， 撮影時のレンズ焦点から測定対象物の表面までの距離

(以下，撮影距離）は $180 \mathrm{~mm}$ であり，これらの画像の

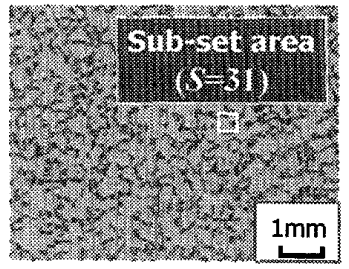

(a) Pattern $A$ (b) Pattern $B$
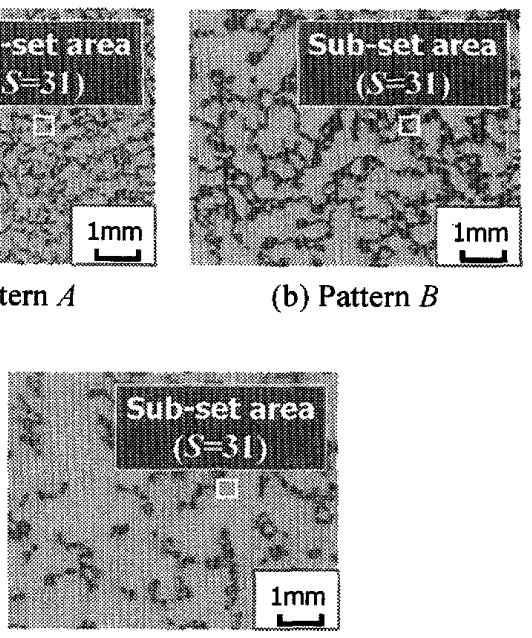

(c) Pattern $C$

Fig.3 Surfaces of test-piece

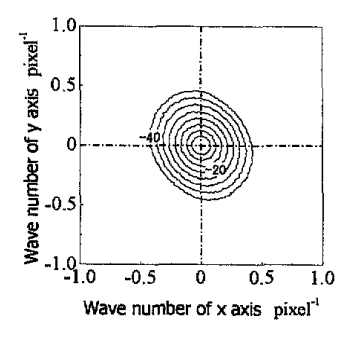

(a) Pattern $A$

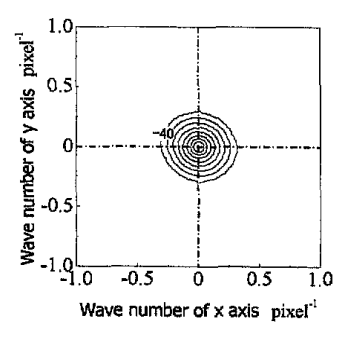

(b) Pattern $B$

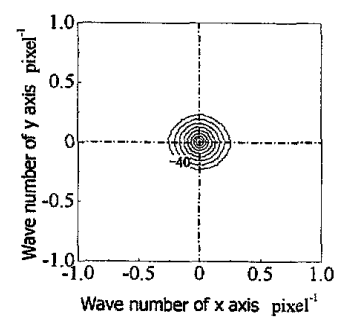

(c) Pattern $C$

Fig.4 Contour diagrams of spatial FFT results

pixel サイズや撮影距離は, 第 3 章における実験でも基本 的に同様とした. この結果, 図 3 に示卞表面模様の撮影 画像には，白い斑点によるランダム模様が確認できる. ここで, 斑点のランダム性は画像の空間周波数成分を知 るための解析法である空間 FFT 解析によって評価する ことが可能であると考えられる.すなわち，画像内にお ける模様の間隔が大きい場合 (ランダム性が弱い場合)， その画像の空閒周波数は小さいことを意味する. その結 果, 空間 FFT 解析で得られるスペクトルは中心波数 $\left(=0 \mathrm{pixel}^{-1}\right)$ に集中し, 当該スペクトル波数の半值幅は 小さくなると考えられる. 
図 4 は撮影した画像全体 $(2381 \times 1901$ pixel $)$ に対して 空間 FFT 解析を行った際に得られたスペクトルを等高 線図で表記した結果であるなお，それぞれの最大值を 基準 $(=0 \mathrm{~dB})$ として正規化し， $-40 \mathrm{~dB}$ から $0 \mathrm{~dB}$ までの間 を $5 \mathrm{~dB}$ 間隔で表記した.これらの結果より，ランダム性 が弱いパターンほどスペクトルの等高線は中心に集中 していることがわかる．また，空間 FFT 解析によって求 めたパターンの半值幅は, パターン $A, B, C$ においてそ れぞれ $0.138 \mathrm{pixel}^{-1}, 0.070 \mathrm{pixel}^{-1}, 0.049 \mathrm{pixel}^{-1}$ であった. そこで，この半值幅をそれぞれのパターンにおけるラン ダム性の定量評価値として, 以後の検討を行った.

変形・ひずみ測定結果の測定精度を評価するため,こ れらの測定対象物に外力や変形を一切加えることなく， 基準画像と比較画像を撮影した。なお，撮影間の時間差 において発生する幾分の輝度変化などに起因する外乱 の影響を削除するため，比較画像は 10 枚連続して撮影 し, 表 1 の解析パラメータを基本として解析を行った. 図 5 は比較画像の 1 枚目における変形測定結果の(a)分布 図，並びに(b)誤差分布，図 6 は同様にひずみ測定結果で ある. 誤差分布中に示す実線は, 测定結果の平均值と標 準偏差から求めた確率密度関数である. 図5(a)及び図6(a) より，理想的に測定される変形・ひずみは 0 であるにも 拘わらず，誤差が生じていることがわかる，また図 5(b) 庈び図 6(b)の結果より，誤差分布はどちらの場合でも正 規分布にしたがっていると言える，なお，図 5(b)に示し た変形誤差分布は 0.08 pixel $\fallingdotseq 1 \mu \mathrm{m}$ を中心としているが， これはカメラシャッターの機械的動作などによりカメ ラがわずかに移動したためであると考えられる．また， ひずみ分布に関しては 0 を中心とした正規分布となって いる.ここで誤差分布を示すデータ群が正規分布にした がう場合，そのバラツキの大きさは標準偏差によって評 価できる ${ }^{(16)}$. そこで本研究では，10枚の比較画像から得 られる変形・ひずみ分布の標隻偏差の平均值を用いるこ とで，測定精度を評価した。

\section{3. 基本測定条件が測定精度に及ぼす影䈏}

$3 \cdot 1$ 表面模様のランダム性の影響 Sub-DIC 法で は, 変形測定において相関值に式(1)で与えられる忘答曲 面近似を行うことによって，サブピクセルレベルでの相 関の極值を求めている.このときサブセット領域内に含 まれるパターンのランダム性が弱い場合や，サブセット サイズが小さい場合, 応答曲面の作成精度が低下し, 変 形分布に誤差が生じると考えられる. そこで, 図 3 に示 した 3 種類の表面模様を用いて, 空間 FFT 解析による半 值幅と測定精度の関係について検討した。 また，撮影距 離を大きくした場合，画像上での表面模様は相対的に細
Table 1 Main analysis conditions on Sub-DIC

\begin{tabular}{ccc}
\hline Sub-set size & $S$ & 31pixel \\
Scan step interval & $\Delta m p$ & 10pixel \\
Averaged point size & $P_{s}$ & 1 \\
\hline
\end{tabular}

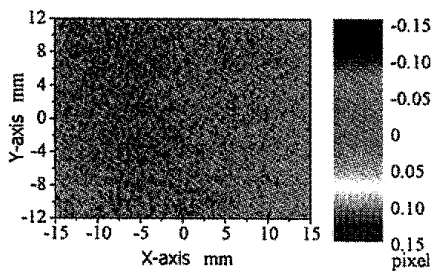

(a) Contour diagram

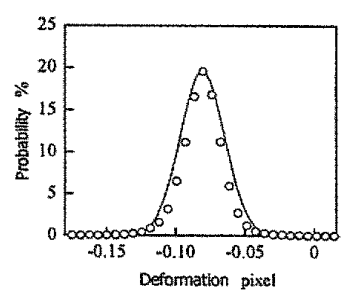

(b) Error distribution results
Fig.5 Deformation distribution measuring results using Sub-DIC

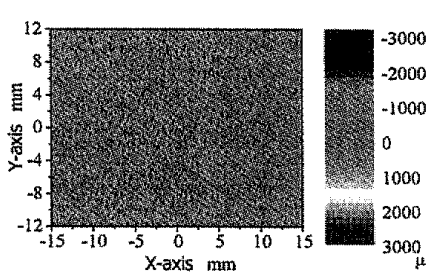

(a) Contour diagram

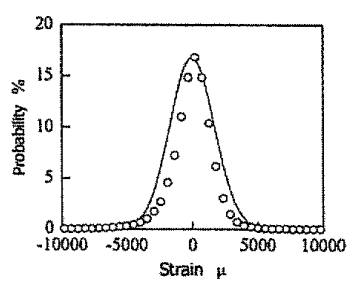

(b) Error distribution results
Fig.6 Strain distribution measuring results using Sub-DIC

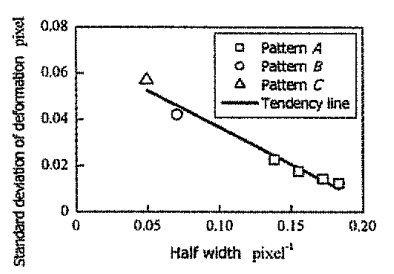

(a) Deformation results

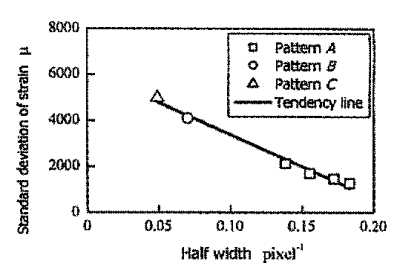

(b) Strain results
Fig.7 Relation between half width of pattern and standard deviation of error distribution

かく撮影される. そこでパターン $A$ の撮影距離を現在の $180 \mathrm{~mm}$ から，200，220，240mm と変化させて画像を撮 影し, 空間 FFT 解析を行った結果, 半值幅はそれぞれ $0.155 \mathrm{pixel}^{-1}, 0.172 \mathrm{pixel}^{-1}, 0.183 \mathrm{pixel}^{-1}$ であった.この結果, 撮影距離を拡大することによって画像内のランダム性 が強くなることを確認できたため，これらの撮影画像に ついても同様に測定精度を評洒した.

図 7 に半值幅と(a)変形分布, (b)Uずみ分布の標準偏差 の関係を示す.これらの結果より，半值幅が大きくなる につれて変形・ひずみ分布の標集偏差は減少しているこ とがわかる，これは，表面模様のランダム性が強くなる ことによって，サブセット領域内のランダム性も強くな り, 応答曲面の作成精度が向上したためであると考えら 
れる.また，図7の結果から半值幅と標準偏差には一定 の関係が認められることから, 空間 FFT 解析の半值幅に よる精度評価方法は有効であると考えられる.なお，以 後の実験及び解析では，パターン $A$ の測定対象物を使用 Lた.

$3 \cdot 2$ サブセットサイズ $S$ の影響サブセットサイ ズと測定精度の関係について検討を行うため, 表 1 に示 す解析パラメータからサブセットサイズのみを変化さ せて解析した．図 8 は(a) $S=31$ pixel，(b) $S=51$ pixel での変 形分布である.この結果より，サブセットサイズを大き くすることで測定誤差は低減されていることがわかる. 図 9 はサブセットサイズ $S$ と(a)変形分布, (b)ひずみ分布 の標準偏差の関係である.この結果より，どちらの場合 でもサブセットサイズ $S$ 大゙さくなるほど標準偏差は減 少しており，その関係は反比例に近い関係であることが わかる.すなわち，サブセットサイズが大きくなった場 合, サブセット領域内に含まれる画素数が多くなるにし たがって応答曲面の作成精度が向上し，標準偏差の減少 につながったと考えられる.

$3 \cdot 3$ スキャンステップ間隔 $\Delta m_{p}$ の影響スキャン ステップ間隔 $\Delta m_{p}$ は隣り合う測定点の閒隔であり，ひず み算出式である式(2)では隣り合う変位值の差をスキャ ンステップ間隔 $\Delta m_{p}$ によって除することによってひずみ を求めている，そのため，スキャンステップ間隔 $\Delta m_{p}$ は 変形分布の測定精度には影響せず，またひずみ分布の測 定精度に対しては，式(2)から理論的には反比例関係にな ると推測される. そこで, 表 1 に示す解析パラメータか らスキャンステップ間隔 $\Delta m_{p}$ のみを変化させて解析を行 うことを通して，スキャンステップ間隔 $\Delta m_{p}$ が測定精度 に及ぼす影響を検討した。

図 10 はスキャンステップ閒隔 $\Delta m_{p}$ と(a)変形分布, (b) ひずみ分布の標準偏差の関係である.なお, 図 10(b)に示 す近似曲線はスキャンステップ間隔 $\Delta m_{p}$ とひずみ分布の 標準偏差の関係が，式(2)から推測されるように反比例関 係であると仮定して最小二乗法により求めたものであ る.図 10(a)の結果より，変形分布の測定精度はスキャン ステップ間隔 $\Delta m_{p}$ に依存しないと言える.また，図 10(b) より，スキャンステップ間隔 $\Delta m_{p}$ はひずみ分布の標淮偏 差に影響を及ぼし，その関係は近似曲線に近い，したが って, 式(2)から推測されるとおりスキャンステップ間隔 $\Delta m_{p}$ と変形分布の標準偏差は関係せず，また，ひずみ分 布の標準偏差とは反比例関係にあると考えられる.

$3 \cdot 4$ 平均化処理サイズ $P_{s}$ の影響本論文にお けるひずみ分布測定法では, 誤差低減を目的として, ひずみ值の平均化処理を施している.図 11 は平均化 処理サイズ $P_{s}$ を(a)1（平均化処理なし），(b)11 とし

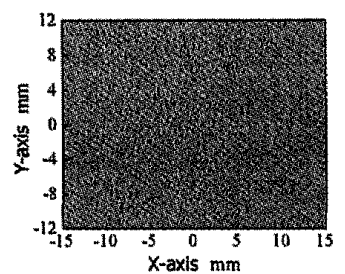

(a) $S=31$ pixel

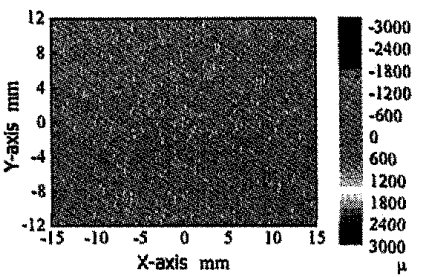

(b) $S=51$ pixel
Fig.8 Strain contour diagram when sub-set size $S$ was changed

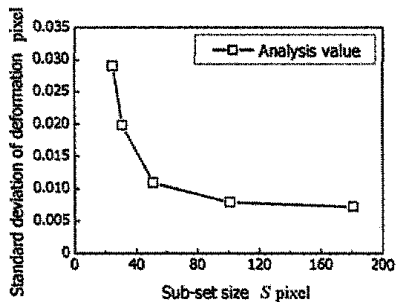

(a) Deformation results

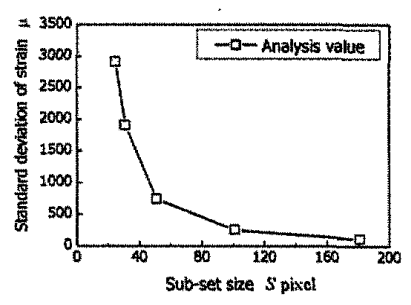

(b) Strain results
Fig.9 Relation between sub-set size $S$ and standard deviation of error distribution

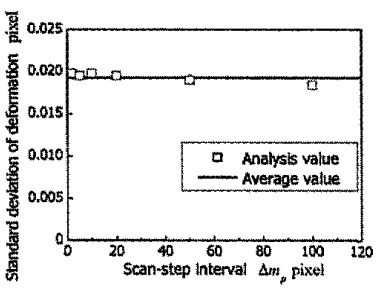

(a) Deformation results

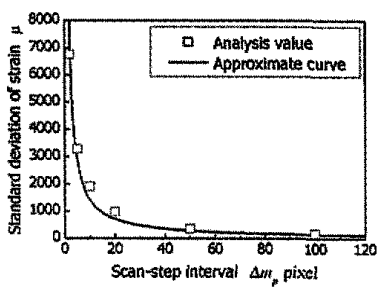

(b) Strain results
Fig.10 Relation between scan-step interval $\Delta m_{p}$ and standard deviation of error distribution

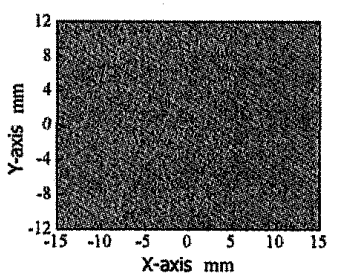

(a) $P_{s}=1$

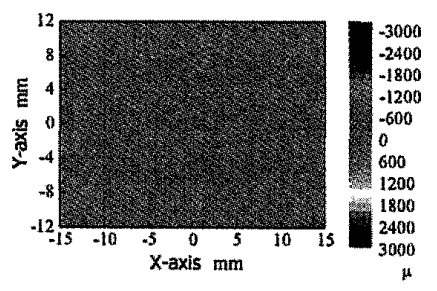

(a) $P_{s}=11$
Fig.11 Strain contour diagram when averaged point size $P_{s}$ was changed

たときのひずみ分布である。この結果より，平均化 処理を施すことでひずみ誤差が低減されることは明 らかである。

ここで測定値の誤差分布が正規分布にしたがう 場合，標準偏差は平均化処理を行えば，中心極限定 理によって減少することが知られている(16). そこで, 中心極限定理による関係を実験的に検証するため, 
表 1 に示す解析パラメータから平均化処理サイズ $P_{s}$ のみを変化させて解析した. 図 12 は平均化処理サイ ズ $P_{s}$ とひずみ分布の標準偏差の関係である.この結 果より，標準偏差は中心極限定理による理論曲線と ほぼ一致していることがわかる，したがって，ひず み分布の誤差は，平均化処理を施すことによって低 減できると言える.

$3 \cdot 5$ 平均化エリアサイズ $A_{s}$ の影響＼cjkstart本節では， 画像上の平均化範囲の pixel サイズである平均化エリア サイズ $A_{s}[$ pixel] が測定精度に及ぼす影響を検討する。こ こでは，平均化処理サイズ $P_{s}$ とスキャンステップ閒隔 $\Delta m_{p}$ を反比例関倸にすることによって平均化エリアサイ ズ $A_{s}$ を一定とし，ひずみ分布の測定精度に及ぼす平均化 エリアサイズ $A_{s}$ の影響を検討した. 図 13 は平均化エリ アサイズ $A_{s}$ を(a)100pixel，並びに(b)200pixel として一定 としたときの, 平均化処理サイズ $P_{s}$ 並びにスキャンステ ップ間隔 $\Delta m_{p}$ とひずみ分布の標準偏差の関係である. 図 $13 の$ (a) と(b)を比較すると，平均化エリアサイズ $A_{s}$ が大 きい場合の方が標準偏差は小さいことがわかる. 一方， 平均化エリアサイズ $A_{s}$ が一定の場合では, 平均化処理サ イズ $P_{s}$ やスキャンステップ間隔 $\Delta m_{p}$ に関係なく標準偏差 はほぼ一定であることがわかる.これは，3・3 節及び3・ 4 節の結果よりひずみ分布の標準偏差は，スキャンステ ップ間隔 $\Delta m_{p}$ 及び平均化処理サイズ $P_{s}$ とそれぞれ共に反 比例関係にあることに依存するものと考えられる。 した がって, 平均化処理によってひずみ分布測定時の誤差の 低隇は可能であるが，その効果は平均化処理を施す範囲 の pixel サイズに依存し，平均化処理を行う範囲に含ま れる測定点数に流存しないと考えられる.

\section{$3 \cdot 6$ 測定対象物に生じたひずみの大きさの影響}

$3 \cdot 6 \cdot 1$ 面外变位を利用したひずみの発生方法 測 定対象物にひずタが生じている場合，変形前後で表面模 様はわずかに変形する，そこで，測定対象物のひずみ状 態がSub-DIC 法の測定精度に及ぼ寸影響を調べるため, 基準画像と比較画像の間に一様なひずみを発生させ，ひ ずみの大きさとひずみ分布の標準偏差の関係について 検討した。 なお，既述のとおり，サブセット領域の変形 を考慮した解析法も提案されているが(8)(13)，本論文では $2 \cdot 1$ 節で示したとおりサブセットの変形を考慮しない方 法を用いている.

ところで，測定対象物に荷重を負荷することによって は測定範囲内に一様ひずみを発生させることは困難で ある，一方，面外変位に視点を向けると，基準画像撮影 後に図 14 のように面外変位 $\Delta L$ が発生した場合，比較画 像が基準画像に対して应大・縮小されることによって, 比較画像にひずみが生じる(15).このひずみ $\varepsilon_{e}$ の大きさに

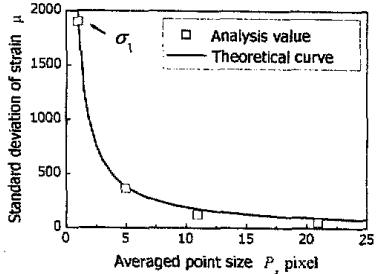

Fig.12 Relation between averaged point size $P_{s}$ and standard deviation of strain error distribution

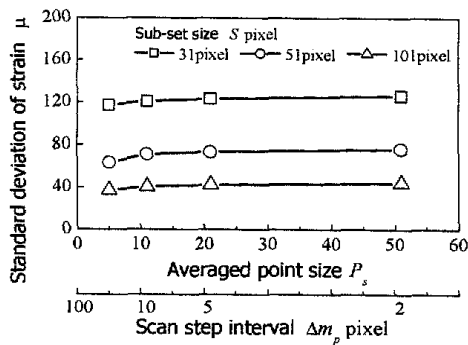

(a) $A_{s}=100$ pixel

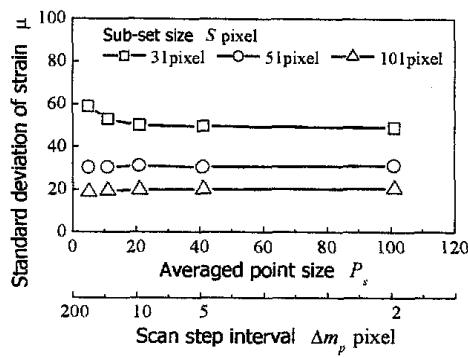

(b) $A_{\mathrm{s}}=200$ pixel

Fig.13 Relation between averaged point size $P_{s}$ and standard deviation of strain error distribution when averaged area size $A_{s}$ was changed

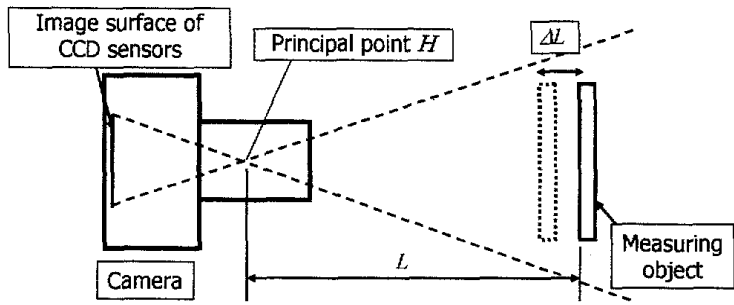

Fig.14 Definition of out-of-plane deformation of measuring object

ついては，面外变位 $\Delta L$ 及び撮影距離 $L$ を用いて，式(4) で表されることが明らかになっている(15).なおる $\Delta L$ の符号 は接近時が正，後退時が負である。

$$
\varepsilon_{e}=\frac{\Delta L}{L}
$$

そこで本実験では，基準画像撮影後にカメラを基淮画 像撮影位置から $0.2 \mathrm{~mm}$ ずつ $\pm 1.0 \mathrm{~mm}$ まで移動させ，比較

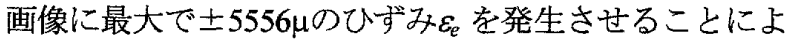


って撮影と解析を行った．解析パラメータは表 1 のとお りとした.

$3 \cdot 6 \cdot 2$ Uずみの大きさと測定精度の関係 図 15 はひずみ $\varepsilon_{e}$ の大きさとひずみ分布の標淮偏差の関係であ る.この結果より，ひずみ 標準偏差は増加していることがわかる.ここで，図 16 は(a)基準画像に対して(b)比較画像に圧縮方向の面ひず みが生じた場合の模式図である. 図 16(a)の黑枠で示すサ ブセット領域内のパターンは，ひずみを受けることで図 16(b)の点線枠のように変形寸るため, サブセット領域内 のパターンは基淮画像と比較画像では異なる.このパタ ーンの変化は誤差の発生要因となり, 䛊差の大きさは図 16 のような面ひずみの場合， $\mathrm{X}$ 軸方向及び $\mathrm{Y}$ 軸方向に 生じるそれぞれのひずみ $\varepsilon_{x} ， \varepsilon$, 積に比例すると考えら れる. 本実験で与えたひずみでは， $\varepsilon_{x}$ と $\varepsilon_{y}$ の大きさが同 じ $\left(\varepsilon_{e}\right)$ であるため， $\varepsilon_{e}$ の二乗に比例して測定誤差は増 加すると考えられる. そこで，ひずみ 標準偏差 $\sigma_{s}$ の関係が式(5)であると仮定して，最小二乗法 により求めた近似曲線を図 15 に示す.

$$
\sigma_{s}=a \varepsilon_{e}^{2}+\sigma_{1}
$$

なお， $\sigma_{1}$ は表 1 の解析条件のもとでひずみ測定を行っ た場合の標準偏差であり，図 12 に示した $\sigma_{1}$ と同一であ る. 図 15 より，標準偏差のプロットと近似曲線が近い 值を示していることがわかる.したがって，测定詨象物 に面ひずみが生じている場合，X軸方向及び $\mathrm{Y}$ 軸方向に 生じるひずみの積に比例して，ひずみ分布の標準偏差が 大きくなることが明らかになった。

\section{4. 結言}

本研究では著者らが用いたデジタル画像相関法の基 本測定条件として測定詨象物が有する表面模様, 及び Sub-DIC 法における解析パラメータと測定精度の関係に ついて検討した，さらに，比較画像におけるひずみ発生 状態の測定精度への影響について, 面外変位を利用した ひずみを用いて検討を行い，その結果について考察した。 以下に，本論文によって明らかになったことを要約する。

1) Sub-DIC 法による測定精度は, 測定対象物の表面模様 のランダム性を示す空間 FFT 解析の半值幅や, サブセ ットサイズの増大に伴って向上する.

2)ひずみ分布に平均化処理を施した場合, 標準偏差は中 心極限定理にしたがって小さくなるが，その割合は平 均化処理を施す範囲の pixel サイズのみに依存する.

3) 比較画像にひずみが発生した場合, $X$ 軸方向と $Y$ 軸方 向に生じるひずみの積に比例してひずみ分布の標準 偏差が大きくなることが明らかになった.

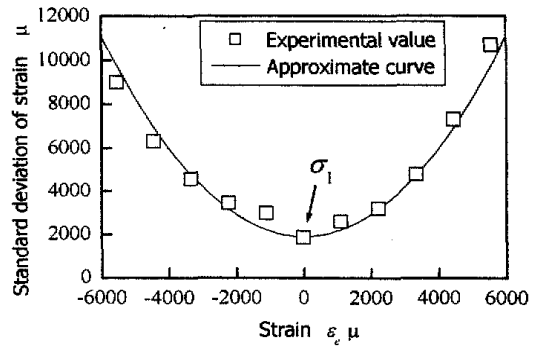

Fig.15 Relation between equivalent strain $\varepsilon_{e}$ and standard deviation of error distribution

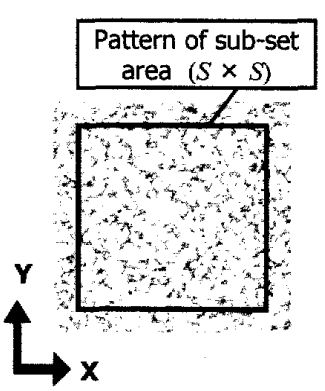

(a) Original image

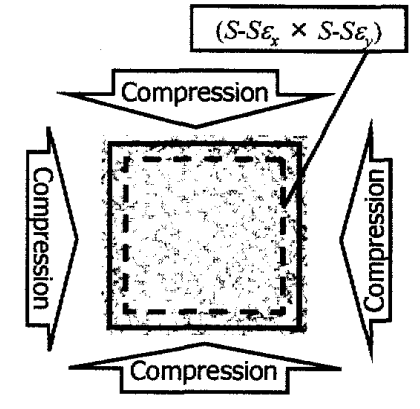

(b) Comparison image

Fig.16 Transformation pattern area on strain

謝辞

本研究の一部は科学技術振興機構による平成 20 年度 シーズ発掘試験 (A：発掘型) の研究補助金によって行 われた.ここに記して謝意を表す。

\section{考文 献}

(1) The Japan Society of Mechanical Engineers Concrete Committee, Health Monitoring on Concrete Structure (in Japanese), (2007), pp."I-1".-"I-6", "I-476", The Japan Society of Civil Engineers.

(2) The Japanese Society for Non-Destructive Inspection, Strain Measurement II (in Japanese), (2007), p.21, The Japanese Society for Non-Destructive Inspection.

(3) Japanese Society for Experimental Mechanics, Experimental Mechanics Handbook (in Japanese), (2008), pp.168-171, Asakura Publishing.

(4) Yamazaki, H., Ishikawa, M., Ando, S., Imai, H., Esashi, M., Ote, A., Sugimoto, E., Measure Engineering Handbook, (2001), pp.730-731, Asakura Publishing.

(5) Shishido, N., Ikeda, T., Miyazaki, N., Strain Measurement in Electronic Packages Using Digital Image Correlation, JSME annual meeting, Vol.6, (2006), pp.219-220. 
(6) Wang, Z. Y., Li, H. Q., Tong, J. W., Shen, F., Aymerich, M., Priolo, P., Dual Magnification Digital Image Correlation Based Strain Measurement in CFRP Laminates with Open Hole, Journal of Composites Science and Technology, Vol.68, No.9 (2008), pp.1975-1980.

(7) Morita, Y., Uchino, M., Arakawa, K., Todo, M., Deformation Analysis of Periodontal Tissues by Digital Image Correlation Method, JSME annual meeting, Vol.1, (2006), pp.835-836.

(8) Matsubara, A., Machida, K., Ogihara, S., Stress Analysis of CFRP Composites by Digital Image Correlation and Intelligent Hybrid Method, Symposium on Evaluation and Diagnosis, Vol.4, (2005), pp.37-40.

(9) Nishikawa, I., Abe, S., Improvement of Digital Image Correlation Method and Application to Strain Measurement of Notch, JSME Kansai district meeting, Vol.80, (2005), pp."7-1"-"7-2".

(10) Uchino, M., Okamoto, T., HIDA, K., Ito, Y., Matsuda, H., Investigation of Strain Analysis Method Around a Hole in a Plate using Multi-Rosette Analysis by Digital Image Correlation Method, Journal of the Japanese Society for Experimental Mechanic, Vol.9, No.2 (2009), pp.96-102.

(11) Shimizu, M., Okutomi, M., Significance and Attributes of Sub-Pixel Estimation on Area-Based Matching, The IEICE Transaction on Communications, Vol.J85-D-II, No.12 (2002), pp.1791-1800.

(12) Uchino, M., Discussion of Strain Analysis using Digital Image Correlation Method (in Japanese), JSEM combination workshop, No.6-1 (2006), pp.36-39.

(13) Machida, K., Morita, K., Nonlinear Stress Analysis by Digital Image Correlation Method and Two-dimensional Nonlinear Hybrid Method, Journal of JSEM, Vol.6, No.1 (2006), pp.36-42.

(14) Uneda, M., Shibahara, M., Matsuishi, M., Ishikawa, K., Iwata, S., Kitamura, K., Studies on Non-Contact Deformation and Stress Measurement Technique of Structures using Sub-pixel Image Processing, Journal of Japan Society for Precision Engineering, Vol.72, No.3 (2006), pp.360-365.

(15) Uneda, M., Matsuishi, M., Iwata, S., Ishikawa, K., Studies on Strain Distribution Measurement using Digital Image Correlation Method - Effect of Out-of-plane Deformation on Strain Easurement Accuracy and its Compensation -, Journal of Japan
Society for Precision Engineering, Vol.73, No.6 (2007), pp.659-664.

(16) Oshikawa, M., Sakaguchi, K., Base of Statistical Science (in Japanese), (1989), pp.56,67, Baihuukan Publishing. 